\title{
Why are you late? Cross-Cultural Pragmatic Study of Complaints in American English and Ukrainian
}

\author{
Iryna Prykarpatska \\ Jagiellonian University in Kraków \\ iradzeva@gmail.com
}

\begin{abstract}
This article examines culture-specific differences in the way a sample of native speakers of American English and Ukrainian make a complaint to their friends. The communication behaviour of both groups of respondents is analyzed within the models of their respective cultures. The research is based on empirical data collected with the help of a questionnaire.
\end{abstract}

\section{Introduction}

The following research is anchored in cross-cultural pragmatics, a field of studies that sprang up in the 1980s. Its emergence is strongly associated with the names of such world-famous scholars as A. Wierzbicka, C. Goddard, D. Tannen, D. Schifrin, Mizutani O. - N. Mizutani etc. The fundamental tenet of cross-cultural pragmatics is best delineated in the following way:

In different societies and different communities, people speak differently; these differences in ways of speaking are profound and systematic, they reflect different cultural values, or at least different hierarchies of values; different ways of speaking, different communicative styles, can be explained and made sense of in terms of independently established different cultural values and cultural priorities (Wierzbicka, 1991: 69).

Taking for granted the isomorphism between language and culture, and viewing human language as a series of acts performed according to socio-cultural conventions, we will 
study the differences in verbal realization of complaints by native speakers of Ukrainian and American English in face-to-face interactions, and interpret them as tangible consequences of intangible mental programs commonly shared by representatives of certain cultural groups.

\section{Models of Culture}

For the present research we use the definition of culture suggested by social anthropologist Geert Hofstede (2004 [1991]). He views culture as "the software of the mind", or collective mental programming of the human mind. According to him, this programming is formed under the influence of a person's social environment and life experience. It starts in the family and continues at school, at the workplace, in the community etc. Culture as a mental program affects all aspects of human activity including verbal communication. In order to find out which differences in verbal behaviours of American English and Ukrainian native speakers are culture specific we use the dimensions of culture introduced by Geert Hofstede (2004 [1991]) and Edward Hall (1976). Despite much criticism that Hofstede's model of cultural variability have caused, it is one of the most widely applied models for cross-cultural comparisons. Hall's dimensions, especially the one referred to as context, will help us compare the communication styles prevalent in the two cultures under analysis. The dimensions are presented below. The first four of them were introduced by Hofstede whereas the last two by Hall.

- Power Distance Index (PDI). It can be low or high. This dimension measures the extent to which the less powerful members of institutions and organizations within a country expect and accept that power is distributed unequally.

- Collectivism vs Individualism (IDV). This is a dimension that measures the degree of relatedness of a person to a group. For example, Hofstede describes this dimension as follows: Individualism is characteristic of societies in which the ties between individuals are loose: everyone is expected to look after himself or herself and his or her immediate family. Collectivism as its opposite applies to societies in which people from birth onwards are integrated into strong, cohesive ingroups, which throughout people's lifetime continue to protect them in exchange for unquestioning loyalty (Hofstede, 1994: 51).

- Femininity vs Masculinity (MAS). Masculinity pertains to societies in which social gender roles are clearly distinct: men are supposed to be assertive, tough and focused on material success, whereas women are supposed to be modest, tender, and concerned with the quality of life. Femininity, on the other hand, is associated with societies in which gender roles overlap: both men and women are supposed to be modest, tender, and concerned with the quality of life. In masculine societies the dominant values are success, competition, money and material things, whereas in feminine ones such values are caring about others and quality of life. 
- Uncertainty avoidance (UA). This dimension measures the degree to which people across societies feel threatened by ambiguities and uncertainties and hence seek to set rules and institutions for the sake of elimination of these ambiguities and uncertainties.

- High vs Low Context. Context is a dimension introduced by Edward Hall (1976), which accounts for the predominant communication style in a given society. Low context societies need little context to interpret messages since all the information is vested in the explicit code of the message (Hall, 1976: 79). In high context societies all the information is encoded in the physical context or internalized in a person and not in an explicit transferable part of the message (Hall, 1976: 79). High context is characteristic of societies or groups where people have close connections over a long period of time. Many aspects of cultural behaviour are not explicitly voiced because most members know how to interpret them due to the years of interaction with each other. Low context is typical of societies where people have many connections but of shorter duration. In these societies, cultural behaviour and beliefs have to be explicitly stated so that those coming into the cultural environment know how to behave.

- Monochronism vs polychronism. Edward Hall (1976) also differentiated between monochronic and polychronic cultures. Monochronism and polychronism are two different versions of the use and treatment of time as a factor which organizes all human activity. Monochronic cultures are characterized by accurate planning, segmentation of time, doing one thing at a time and strict keeping to schedules and timetables. In such cultures, time is treated as a commodity, whereas in polychronic cultures as a philosophical concept. Members of polychronic societies tend to be engaged in several actions at the same time.

\section{Ukrainian vs North American Models of Culture}

We describe North American model of culture making use of findings provided by G. Hofstede and E. Hall for the USA. Unfortunately, their findings do not include Ukraine because none of them researched it. However, the Ukrainian scores along Hofstede's four dimensions can be deduced by means of comparison with other countries whose scores are provided by him. For the comparison to be possible we use the cultural dimensions ranking list for European nations constructed by Mikułowski-Pomorski (2006:325-326), which also includes Ukraine. According to it, among twenty nine European countries Ukraine is first and Russia is second in the power distance ranking. Based on Geert Hofstede's findings ${ }^{3}$ et al. (2004), the estimated value of Russian power distance index is 95. It implies that the value of Ukrainian power distance index is more than 95 but less than 110 (1-110 power distance scale). As far as individualism index is concerned, Ukraine is twentieth, Russia is nineteenth and Turkey is twenty first in the individualism ranking list. Since Russian individualism index is 39 and Turkish 37, Ukrainian individualism index is 38. Ukrainian masculinity as well as uncertainty 
avoidance indices were deduced in exactly the same way. The definition of Ukrainian model of culture in terms of Hall's cultural dimensions was carried out by the author of the present thesis based on her experience as a native user of Ukrainian culture as well as analogy with other Slavic country such as Poland, which was described by Lubecka (2000:45). On the basis of the aforementioned sources we compile Table 1. It should be remembered that Ukrainian scores are just approximate values that is why they are preceded by the approximation symbol $\sim$.

\begin{tabular}{|l|l|l|}
\hline Dimensions & Ukraine & USA \\
\hline Individualism & $\sim 38$ & 91 \\
\hline Power Distance & $\sim 96$ & 40 \\
\hline Masculinity & $\sim 40$ & 62 \\
\hline Uncertainty Avoidance & $\sim 93$ & 46 \\
\hline Time & Poly & Mono \\
\hline Context & High & Low \\
\hline
\end{tabular}

Table 1: Value Dimensions for Ukraine and the USA

North American culture has very strong individualistic tendencies. Personal independence and rights are the values of paramount importance. North Americans take care of their privacy and respect the right to privacy of other people. Interference with the affairs of other people is unacceptable. North American society is an egalitarian one; authority is not recognized just on the basis of age, wealth or origin. The North American ideal is that of a self-made person. Ambition and competitiveness are the basic values of North American culture. Any kind of dogmatism is rejected and seeking a compromise and tolerance for otherness are positively evaluated. North Americans do not like playing subtle word games. They express their communicative intentions explicitly by means of unambiguous words and gestures. In this way they save their own time and that of other people. North Americans treat time as a finite resource that requires sensible management. That is why they are very ardent in keeping to deadlines and timetables.

Unlike the USA, Ukraine displays rather collectivistic tendencies that have a very long tradition. They can be traced back to the times when land was the most important factor of production and fundament of Ukrainian life. Privacy is not the first rate value and the word "privacy" entered into Ukrainian vocabulary not so long ago. The most important Ukrainian cultural values are family, care of children and aged parents as well as maintaining strong, long-term friendship bonds. According to the norms of Ukrainian culture it is important to pay respect to older people and those of higher social status. This is an outcome of high power distance of Ukrainian culture. Ukrainians are very emotional, open and sincere show of emotions is positively evaluated since it is considered human. Non-competitiveness and modesty that can be judged as lack of self- 
confidence, these are the evidences of feminine tendencies in Ukrainian culture. In faceto-face interactions Ukrainians resort to allusion, irony and tend to respond to a number of communicative situations with phrases from widely known jokes. Such verbal behaviour points to high-context communication style.

\section{Collection of empirical data}

The present research is based on empirical data collected with the help of 1) natural observation; 2) participant observation; 3) specially constructed open-ended questionnaires. Such a complex multi-method approach allows us to capture the authenticity, creativity and richness of naturally occurring speech and at the same time to control the many variables inherent in language use so that the data from different individuals can be meaningfully compared. A total of 94 respondents participated in the survey: 49 Ukrainians ( 23 females vs. 26 males) and 45 North Americans ( 25 females vs. 20 males). The respondents were native speakers of their respective languages, aged 16 to 55 or over. Their level of education ranged from secondary to post-graduate studies and they represent different social classes of their respective societies.

A total of 118 verbal items was produced, which were analyzed and compared by means of both qualitative and quantitative methods.

The respondents were asked to provide spontaneous verbal reactions to the situation described below:

You are meeting your friend. You arrive on time and find out that your friend is late. After 15 minutes of waiting your friend finally comes. You see him/her and say:

\section{Criteria of Analysis}

As mentioned before, the object of the present research is the speech act of complaint. It belongs to expressive speech acts in Searle's taxonomy (Searle, 1989), since its illocutionary force also consists of the conveyance of a speaker's psychological state to a hearer. Therefore, the speech act of complaint can be defined as an illocutionary act in which the speaker (the complainer) expresses his/her negative opinion/feelings towards the things described in the proposition (the complainable) and for which he/she holds the hearer (the complainee) responsible either directly or indirectly (Trosborg, 1995: 312). Olshtain and Wienbach (1993) defined a set of preconditions to be fulfilled for the speech act of complaint to take place. They are the following:

1) A hearer performs a socially unacceptable act (abbreviated SUA) that is contrary to a social code of behavioural norms shared by a speaker (abbreviated $\mathrm{S}$ ) and a hearer (abbreviated $\mathrm{H}$ ).

2) S perceives the SUA as having unfavourable consequences for herself, and/or for the general public. 
3) The verbal expression of S relates post factor directly or indirectly to the SUA, thus having the illocutionary force of censure.

4) S perceives the SUA as: a) freeing $S$ (at least partially) from the implicit understanding of a social cooperative relationship with $\mathrm{H} ; \mathrm{S}$ therefore chooses to express her frustration or annoyance; and (b) giving $\mathrm{S}$ the legitimate right to ask for repair in order to undo the SUA, either for her benefit or for the public benefit. It is the latter perception that leads to instrumental complaint aimed at "changing things" that do not meet with our standards or expectations. The main goal of such instrumental complaint is to ensure that $\mathrm{H}$ performs some action of repair as a result of the complaint (Olshtain and Wienbach, 1993: 108). According to Leech's (1983) classification of illocutionary acts, complaints are referred to as conflictive illocutions since they cause offence and hence may destroy comity and harmony between the interlocutors. Based on Brown and Levinson's (1992:67) model of politeness for face-threatening speech acts (abbreviated FTAs), the speech act of complaint threatens both the negative and positive face of a hearer. This is why the speakers need some strategies and their proper lexico-syntactic realizations to mitigate the complaints and hence avoid personal conflicts in communication.

According to Leech's (1983) classification of illocutionary acts, complaints are referred to as conflictive illocutions since they cause offence and hence may destroy comity and harmony between the interlocutors. Based on Brown and Levinson's (1992:67) model of politeness for face-threatening speech acts (abbreviated FTAs), the speech act of complaint threatens both the negative and positive face of a hearer. This is why the speakers need some strategies and their proper lexico-syntactic realizations to mitigate the complaints and hence avoid personal conflicts in communication.

The verbal reactions to the situation described above were analyzed and compared using the following criteria:

1) the use of strategies by North Americans and Ukrainians while making a complaint to a friend;

2) lexico-syntactic realizations of complaint strategies and frequency of occurrence of certain lexico-syntactic patterns within North American vs. Ukrainian verbal repertoires;

3) the use of lexical internal modification markers by Ukrainians vs. North Americans;

4) the occurrence of poly-move complaints in North American vs. Ukrainian complaint repertoires and determination of the average number of moves within one North American vs. Ukrainian poly-move complaint.

Based on the model of politeness for face-threatening speech acts (FTAs) introduced by Brown and Levinson (1992), the five point - complaint severity scale established by Olshtain and Weinbach (1987) and complaint strategies defined by Anna Trosborg (1995), we set up the following complaint severity scale: 
1) Not perform a FTA. By using this strategy, the speaker opts out of making a complaint completely and behaves as though a SUA did not take place.

2) Express annoyance and disapproval. With this strategy the speaker does not explicitly refer to either the SUA or the H, but just signals his/her notice of the SUA and passes his/her judgment on it. This strategy includes the following substrategies which differ from each other by the degree of severity implied:
a. joke
b. irony
c. hint
d. conventionally indirect disapproval (CID)
e. open disapproval (OD)

3) Explicit Complaint. The speaker produces his/her complaint by making direct reference to either a SUA or/and $\mathrm{H}$ or his/her personal losses/costs caused by the SUA and asks for compensation. This strategy can be realized by means of the following sub-strategies:
a. statement that the SUA took place
b. request that contains forbearance
c. mitigated request for repair
d. unmitigated request for repair

4) Warning. The speaker produces an open FTA and instigates sanctions against the H. The warning can be realized as:
a. mitigated warning
b. unmitigated warning

5) Immediate threat encompasses open attack on $H$ including verbal abuse.

\section{Results of Analysis}

Table 2 shows the frequency of occurrence of complaint strategies in Ukrainian and American verbal reactions to the analyzed situation.

\begin{tabular}{|l|l|r|r|}
\hline Strategies & $\begin{array}{r}\text { North American } \\
\text { (\%) }\end{array}$ & $\begin{array}{r}\text { Ukrainian (\%) } \\
\hline \text { Not perform a FTA }\end{array}$ \\
\hline \multirow{2}{*}{$\begin{array}{l}\text { Annoyance and } \\
\text { Disapproval }\end{array}$} & Joke & 0 & 20.8 \\
\cline { 2 - 4 } & Irony & 0 & 3.7 \\
\cline { 2 - 4 } & Hint & 50 & 3.7 \\
\cline { 2 - 4 } & $\begin{array}{l}\text { Conventionally Indirect } \\
\text { Disapproval }\end{array}$ & 19.2 & 11.5 \\
\cline { 2 - 4 } & Open Disapproval & 0 & 17 \\
\hline Explicit complaint & $\begin{array}{l}\text { Statement that the SUA took } \\
\text { place }\end{array}$ & 0 & 7.4 \\
\cline { 2 - 4 } & $\begin{array}{l}\text { Request that contains } \\
\text { forbearance }\end{array}$ & 1.9 & 0 \\
\cline { 2 - 4 } & Mitigated request for repair & 0 & 0 \\
\hline
\end{tabular}




\begin{tabular}{|l|l|r|r|}
\hline & Unmitigated request for repair & 0 & 2 \\
\hline \multirow{3}{*}{ Warning } & Mitigated warning & 0 & 0 \\
\cline { 2 - 4 } & Unmitigated warning & 0 & 4 \\
\hline Immediate threats & 0 & 0 \\
\hline
\end{tabular}

Table 2: North American and Ukrainian complaint strategies

According to the results obtained on the first level of analysis North Americans while making a complaint to their friends for being late prefer the least severe strategies. They either opt out of making a complaint completely or signal their notice of the SUA by hints or in a conventionally indirect way. Although hints are also a very popular strategy for signalling that the SUA occurred among Ukrainian respondents, they use it less often than their North American counterparts (31.5 vs. 50), and the same can be said about conventionally indirect disapprovals (11 vs. 19.2). By contrast, Ukrainians seem less restricted in the use of more severe strategies such as open disapprovals ( 0 vs. 17), unmitigated request for repair (0 vs. 2 ) and even unmitigated warning (0 vs. 4 ). Besides, unlike North Americans, Ukrainians also use such strategies as jokes and irony. This evidences the tendencies for less standard and more creative verbal reactions in the situation described.

The obtained results confirm our observations that the acceptable level of closeness between friends differs in two cultures under analysis. The use of more severe strategies by Ukrainian respondents evidences that social distance between Ukrainian friends is weaker than between their North American counterparts. According to Ukrainian norms friends have to be open and sincere with each other even if it trespasses on their privacy and personal autonomy, whereas respect and right for each other's personal autonomy keeps North American friends on a fair distance and determines their respective verbal and non-verbal behaviour.

On the second level of analysis, the strategies used by North American and Ukrainian respondents were analyzed according to their lexico-syntactic realizations. Ukrainian examples are followed by their English literal translations (abbreviated Eng. Lit.) provided in brackets. Hints are realized with the following semantic-syntactic patterns:

1. Exclamatives:

$\mathbf{A m}_{\mathbf{1}}=$ Interj! + FA +VP.

(1) Oh! You made it.

2. Elliptic exclamatives:

$\mathbf{U k r}_{\mathbf{1}}=$ Interj + ADV!.

(1) Нy нарештi! (Eng. Lit. Oh finally!)

3. Personal embedding clause with opinion/feelings expressions:

$\mathbf{A m}_{\mathbf{1}}=\mathrm{I}$ was afraid/worried/thought + (that) - clause.

$\mathbf{U k r}_{\mathbf{1}}=$ Я думав/думала + (що) - clause.

(1) I was afraid I had the days mixed up.

(2) Я думала, ти вже не прийдеш. (Eng. Lit. I thought you won't come).

4. Elliptic "to make sure" general questions: 
$\mathbf{A} \mathbf{m}_{\mathbf{1}}=$ Pronoun $+\mathrm{ADV} ?$

(1) Everything ok/alright?

$\mathbf{U k r}_{\mathbf{1}}=$ Pronoun $+\mathrm{ADV} / \mathrm{VP}$ ?

(1) Все добре? / Щось сталося? (Eng. Lit. All good? / Anything happened?)

$\mathrm{Am}_{2}=\mathrm{NP}$ ?

(1) Traffic problems?

$\mathbf{U k r}_{\mathbf{2}}=$ Preposition $+\mathrm{NP}+\mathrm{VP}$ ?

(1) В корок попала? (Eng. Lit. In traffic got?)

5. General "to make sure"-questions:

$\mathbf{A} \mathbf{m}_{1}=$ Is/are + pronoun $/ \mathrm{FA}+\mathrm{ADV} ?$

(1) Are you ok? / Is everything alright?

$\mathbf{A m}_{2}=\mathrm{Did}+$ Pronoun $/ \mathrm{FA}+\mathrm{VP}+\mathrm{NP}$ ?

(1) Did I have the time wrong?

(2) Did you get in traffic?

$\mathbf{U k r}_{\mathbf{1}}=$ Preposition $+\mathrm{FA}$ genitive case + Pronoun + ADV?

(1) В тебе все гаразд? (Eng. Lit. In you all good?)

6. Impersonal embedding clause with opinion/feelings expression:

$\mathbf{A m}_{\mathbf{1}}=$ It's nice/about time + (of) + FA +VP.

(1) It's nice of you to show up.

(2) It's about time you got a cellphone.

Table 3 depicts the percentage of the above semantic-syntactic patterns in Ukrainian vs. North American hints.

\begin{tabular}{|c|c|c|c|}
\hline $\mathrm{n} / \mathrm{n}$ & Semantic-syntactic patterns & $\begin{array}{r}\text { North American } \\
\text { (\%) }\end{array}$ & Ukrainian (\%) \\
\hline 1 & Exclamatives & 3.8 & 0 \\
\hline 2 & $\begin{array}{l}\text { Personal embedding clause with } \\
\text { opinion/feeling expressions }\end{array}$ & 34.6 & 11.8 \\
\hline 3 & $\begin{array}{l}\text { Impersonal embedding clause with } \\
\text { opinion/feeling expressions }\end{array}$ & $7.7 \%$ & 0 \\
\hline 4 & General "to make sure"- general questions & $46 \%$ & 5.9 \\
\hline 5 & Elliptic exclamatives & 0 & 29.4 \\
\hline 6 & Elliptic "to make sure" - general questions & 7.7 & 53 \\
\hline
\end{tabular}

Table 3: North American and Ukrainian hints

As we can see from Table 3 North Americans seem to prefer negative politeness syntactic patterns, whereas Ukrainians opt for the positive ones. The preference for the elliptic exclamatives and elliptic questions fully corresponds to short social distance between Ukrainian friends. In collectivist and high-context communication societies the interpersonal bonds are very close, that is why a lot of things can go unsaid. North Americans, as representatives of individualist and low context communication societies in which personal freedom is highly valued and social distance positively evaluated, show preference for embedding clauses and full general questions. Besides, they also 
use impersonal embedding clauses, which are not used by their Ukrainian counterparts. Linguistic distance created by means of personal and impersonal complex clauses signals that social distance between North American friends is greater than between their Ukrainian counterparts.

The following lexico-syntactic realizations of conventionally indirect disapprovals were detected in American and Ukrainian repertoires:

1. What/Що - questions about the event in general:

$$
\begin{aligned}
& \mathbf{A m}_{\mathbf{1}}=\text { What + VP? } \\
& \mathbf{U k r}_{\mathbf{1}}=\text { Що + VP? }
\end{aligned}
$$

(1) What happened (to you)?

(2) Що сталося?

2. What/Що - questions about the event in general:

$$
\begin{aligned}
& \mathbf{A m}_{\mathbf{1}}=\mathrm{What}+\mathrm{VP}+\mathrm{FA}+\mathrm{ADV} ? \\
& \mathbf{U k r}_{\mathbf{1}}=\text { Щo + FA + VP? }
\end{aligned}
$$

(1) What kept you so long?

(2) Що тебе затримало? (Eng. Lit. What you kept?)

3. Where/Дe-questions about the particulars of the event:

$\mathbf{A m}_{\mathbf{1}}=$ Informal FA + Where +VP+FA+VP?

$\mathbf{U k r}_{\mathbf{1}}=$ Дe $+\mathrm{FA}+\mathrm{VP}$ ?
(1) Dude, where have you been?
(2) Де ти ходиш? (Eng. Lit. Where you walk?)

4. Colloquial impersonal passive Дe(where)- questions about the particulars of the event:

$\mathbf{U k r}_{\mathbf{1}}=$ Conj./Particle + де $+\mathrm{FA}_{\text {objective case }}+\mathrm{VP}$ present/past tense?

(1) I де тебе носило? (Eng. Lit. And where you (were) carried? It should be understood as "And were did you hang around?")

(2) Ну тебе носить? (Eng. Lit. So where you (are) carried? It should be understood as "And where are you hanging around?")

Ukrainian verb "носити" when used impersonally has a colloquial meaning "to hang about/around". Thus, the question "І де тебе носило?" is translated into English as "Where did you hang about?"

5. Yomy(why)-questions about the particulars of the event:

$\mathbf{U k r}_{\mathbf{1}}=$ Чому $+(\mathrm{FA})+\mathrm{VP} ?$

(1) Чому спізнюєшся? (Eng. Lit. Why (are you coming) late?)

The percentage of the semantic-syntactic patterns by means of which North American and Ukrainian conventionally indirect disapprovals are realized is represented in Table 4 below.

\begin{tabular}{|l|l|r|r|}
\hline $\mathrm{n} / \mathrm{n}$ & Semantic-syntactic patterns & American (\%) & Ukrainian (\%) \\
\hline 1. & What/Щo-questions about the event in general & 80 & 16.7 \\
\hline$\underline{2}$ & $\begin{array}{l}\text { What/Щo-questions about the particulars of the } \\
\text { event }\end{array}$ & 10 & 16.7 \\
\hline
\end{tabular}




\begin{tabular}{|l|l|r|r|}
\hline 3 & $\begin{array}{l}\text { Where/Дe-questions about the particulars of the } \\
\text { event }\end{array}$ & 10 & 16.7 \\
\hline 4 & $\begin{array}{l}\text { Colloquial impersonal Дe-questions about the } \\
\text { particulars of the event }\end{array}$ & 0 & 33.3 \\
\hline 5 & $\begin{array}{l}\text { Чomy(why)-questions about the particulars of the } \\
\text { event }\end{array}$ & 0 & 16.7 \\
\hline
\end{tabular}

Table 4: North American and Ukrainian conventionally indirect disapprovals

What/Що-questions about the event in general are the most indirect interrogative sentences, since they presuppose lack of knowledge about what kind of event occurred. As shown in Table 4, $80 \%$ of American indirect disapprovals are realized with questions asking/interrogating about the event in general. Ukrainians, on the other hand, prefer the questions interrogating about the particulars of the event, since only $16,7 \%$ of conventionally indirect disapprovals are realized as questions about the event in general. Special questions about the particulars of the event are more direct ways of expression of conventionally indirect disapproval, since they presuppose knowledge about the kind of event that took place. Besides, Ukrainian impersonal Дe-questions are an informal and colloquial way of telling somebody off for being late.

Therefore, it may be concluded that weak social distance between Ukrainian friends allows them to construct their conventionally indirect disapprovals in a conventionally more direct and informal way, whereas greater social distance between American friends requires that their conventionally indirect disapproval should be expressed in the most indirect and neutral way.

The complaint strategies not commonly shared by American and Ukrainian respondents include jokes, ironies, open disapprovals, statements about the socially unacceptable act (SUA), requests that contain forbearance, unmitigated request for repair, and mitigated warning.

Ukrainian open disapprovals are expressed with the following semantic-syntactic formulas:

1. Скільки (how long)- rhetoric questions with impersonal modal predicative of possibility "можна":

$\mathbf{U k r}_{\mathbf{1}}=$ Interj. + Particle + скільки + можна + Infinitive?

(1) O, ну скільки можна чекати? (Eng. Lit. Oh, so/well for how long (it) may be waited?)

The Ukrainian equivalent of English modal verbs of possibility/permission such as can/may is "могти" which conjugates in accordance with tense, person and number, whereas "можна" is just an impersonal modal forming part of a complex verbal predicate.

2. Exclamatives:

$\mathbf{U k r}_{\mathbf{1}}=$ Pronoun personal, 1p.pl + Intensif. particle $+\mathrm{VP}+\mathrm{ADV}$ of manner + ADV of time.

(1) Ми ж домовлялися зустрітися рівно о 5:00. (Eng. Lit. We did agree to meet at 5:00 sharp.) 
3. Elliptic optatives:

$\mathbf{U k r}_{\mathbf{1}}=$ Modal Verb ${ }_{\text {of possibility in past t. }}+$ optative particle $+(\mathrm{NP})+$ Infinitive.

$\mathbf{U k r}_{\mathbf{1}}=$ Optative Particle $+\mathrm{VP}$ past tense

(1) Могла/міг би смс скинути. (Eng. Lit. (You) could have thrown an sms. It should be understood as "You could have sent me an sms").

(2) Хоча би попередила/попередив. (Eng.Lit. (You) could have warned me)

In Ukrainian apart from declarative, imperative, and interrogative sentences there are also optative sentences which have the modal meaning of desirability if used with non-past reference, but reproach and reprimand - when used with past reference. The sentences described above are used with past reference, therefore they express reprimand.

4. Intensified Declaratives:

$\mathbf{U k r}_{\mathbf{1}}=$ Pronoun [personal, I Pr.Sg] $+(\mathrm{ADV}$ of time $)+\mathrm{ADV}$ of place $+(\mathrm{NP}-\mathrm{based}$ adverbial of time) + VP.

(1) Я вже задовбався тут чекати. (Eng. Lit. I am already sick and tired of waiting here)

(2) Я тут 15 хвилин мерзну. (Eng. Lit I here 15 minutes freeze)

(3) Я вже чекаю 15 хвилин. (Eng.Lit. I already wait 15 minutes)

The English phrase "sick and tired" is not a full equivalent of the Ukrainian intransitively used verb "задовбався". "Sick and tired" is just a spoken way of expressing annoyance, whereas “задовбався" alongside its spoken use is a slang euphemism of an Ukrainian taboo word that is rendered into English by a verb "fuck". Apart from slang words, the declaratives are also intensified with the adverbs of time, since they emphasize the amount of losses/costs incurred by the speaker due to the socially unacceptable act (SUA) committed by a hearer.

Ukrainian statements about SUA were realized using the following semanticsyntactic patterns:

1. Declaratives with explicit reference to the agent of SUA.

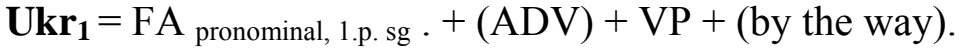

(1). Ти спізнився. (Eng. Lit. You are late by the way)

(2) Ти спізнилася. (Eng. Lit. You are late).

(3) Ти як завжди спізнюєшся. (Eng.Lit. You are as always late).

(4) Ти замахав. (Eng.Lit. You got (me).

The Ukrainian word "замахав" is a slang word used by young people with the meaning of "made me annoyed, nervous".

Ukrainian unmitigated request for repair was realized with:

1. Elliptic nominal construction:

$\mathbf{U k r}_{\mathbf{1}}=$ Preposition $+\mathrm{FA}_{\text {Genitive case }}+\mathrm{NP}$.

(1). 3 тебе кава. (Eng. Lit. Coffee is on you). 
Ukrainian unmitigated warning was realized with:

1. Declaratives with future reference:

$\mathbf{U k r}_{\mathbf{1}}=\mathrm{ADV}$ of future time + Pronoun $_{\text {personal, } 1 \text { p. sg. }}+\mathrm{VP}$.

(1) Наступного разу я спізнюсь. (Eng. Lit. Next time I'll be late).

Ukrainian ironies are conveyed with the following semantic - syntactic patterns:

1. Elliptic adverbial clauses:

$\mathbf{U k r}_{\mathbf{1}}=\mathrm{ADV}$ of degree $+\mathrm{ADV}$.

(1) Дуже гарно. (Eng. Lit. Very nice).

$\mathbf{U k r}_{\mathbf{2}}=\mathrm{FA}_{\text {pronominal } 2 \text { p. sg. }}+\mathrm{ADV}$ of degree $+\mathrm{ADV}$ of time.

(1) Ти майже вчасно. (Eng.Lit. You are almost on time)

Ukrainian jokes are expressed with:

1. Conversationally elliptic negated inversive clause with past reference:

$\mathbf{U k r}_{2}=\mathrm{VP}_{\text {negated }}+$ Intensif. particle $+\mathrm{ADV}$ of time.

(1) Не пройшли і три дні... (Eng. Lit. Scarcely had three days passed, (when you came).

The clause is called conversationally elliptic because its second part, though provided in the English translation for the sake of interpretation, is deliberately omitted. The full non-elliptic version of this clause is well-known to every Ukrainian since his/her childhood, because it is amply used in Ukrainian and Russian fairy-tales for emphasizing how fast something happened. In the situation analyzed, the use of this phrase causes a humorous effect as it is used in a situation when a friend is late. Moreover, three days are ironically commented upon as a very short period of time.

1. Declarative clause with modal adverb of certainty (with past reference):

$\mathbf{U k r}_{\mathbf{1}}=\mathrm{FA}+$ Modal Adverb of certainty $_{\mathrm{ADV}}$ of direction $+\mathrm{VP}$ past tense.

(1) Ти напевно через Париж добирався.

(Eng. Lit. You must have come via Paris).

American request that contains forbearance is realized with conditional imperatives and the politeness marker "please".

$\mathbf{A m}_{\mathbf{1}}=\mathrm{ADV}$ of future time + please $+\mathrm{VP}_{\text {imp }}+$ if-clause.

(1) Next time please call if you know you'll be more than 10 minutes late.

On the third level of our analysis, American English and Ukrainian complaint repertoires were analyzed in terms of the use of lexical internal modification markers, whose function consists in modifying the severity of a complaint. A complaint may be mitigated by means of downgraders and aggravated by means of upgraders. 
Tables 5 and 6 illustrate the downgraders and upgraders detected in Ukrainian and American speeches.

\begin{tabular}{|c|c|c|c|c|c|}
\hline \multicolumn{6}{|c|}{ Downgraders } \\
\hline $\mathbf{n} / \mathbf{n}$ & $\begin{array}{l}\text { Modification } \\
\text { markers }\end{array}$ & Ukrainian & Freq.(times) & American & $\begin{array}{l}\text { Freq.(ti } \\
\text { mes) }\end{array}$ \\
\hline 1 & Downtoners & $\begin{array}{l}\text { Напевно (likely) } \\
\text { майже (almost) }\end{array}$ & 2 & - & 0 \\
\hline 2 & Hedges & До речі (by the way) & 1 & - & 0 \\
\hline 3 & Subjectivizers & $\begin{array}{l}\text { Дума(в)/(ла) } \\
\text { thought) }\end{array}$ & 2 & $\begin{array}{l}\text { I was afraid } \\
\text { I thought } \\
\text { I was worried }\end{array}$ & 6 \\
\hline 4 & $\begin{array}{l}\text { Politeness } \\
\text { markers }\end{array}$ & 0 & & Please & 1 \\
\hline & & & & & \\
\hline
\end{tabular}

Table 5: Downgraders in Ukrainian and American English complaints

\begin{tabular}{|c|c|c|c|c|c|}
\hline \multicolumn{6}{|c|}{ Upgraders } \\
\hline $\mathbf{n} / \mathbf{n}$ & $\begin{array}{l}\text { Modification } \\
\text { markers }\end{array}$ & Ukrainian & Freq.(times) & American & Freq.(times) \\
\hline 1 & Intensifiers & $\begin{array}{l}\text { Ну (well/so) } \\
\text { Ну i (well/so) } \\
\text { Як завжди (as always) } \\
\text { Вже (already) } \\
\text { Дуже (very) } \\
\text { Рівно (sharp) } \\
\text { Ж (did) }\end{array}$ & 15 & $\begin{array}{l}\text { Hey } \\
\text { So }\end{array}$ & 4 \\
\hline 2 & $\begin{array}{l}\text { Lexical } \\
\text { intensification }\end{array}$ & $\begin{array}{l}\text { Замахав ((You) annoyed } \\
\text { mе) } \\
\text { Мерзну (I freeze) } \\
\text { Носило (You hung } \\
\text { about) } \\
\text { Задовбався (sick and } \\
\text { tired) }\end{array}$ & 5 & - & 0 \\
\hline
\end{tabular}

Table 6: Upgraders in Ukrainian and American English complaints

As the results show both Ukrainian and North American respondents use approximately the same amount of downgraders while complaining to their friends for being late. But as far as the use of upgraders is concerned, Ukrainians are the ones who tend to magnify their complaints with intensifying particles and slang words. Hence the complaints made by Ukrainians sound more severe and informal. The analysis of internal lexical modification markers definitely shows that Ukrainian norms of friendship allow greater directness while making a complaint. 
The collected empirical data illustrates that the speech act of complaint can be performed by means of a single move ${ }^{2}$ or a sequence of moves (poly-move complaints). Therefore, on the fourth level of our research the complaints made by Ukrainians and North Americans were analyzed according to the number of moves made when performing the speech act. According to our data, the poly-move complaints are realized either as a sequence of complaint strategies of the same/different degree of severity or as a complaint strategy supported by some external move.

There were no supportive moves found in the Ukrainian complaint repertoire. North Americans, by contrast, tend to provide supportive reasons for externalization of their notice of the socially unacceptable act (SUA), and hence justify their behaviour and reduce the risk of the hearer's face damage. Americans' supportive reason that follows their complaint strategies is "I was getting worried". The table 7 reflects the number of poly-move complaint realizations in Ukrainian as compared to the American verbal repertoires.

\begin{tabular}{|l|r|r|r|}
\hline Respondents & Total respondents & $\begin{array}{l}\text { The number of poly- } \\
\text { move complaints }\end{array}$ & $\begin{array}{l}\text { The average number } \\
\text { of moves within one } \\
\text { poly-move complaint }\end{array}$ \\
\hline American & 45 & 8 & 2 \\
\hline Ukrainian & 49 & 4 & 2 \\
\hline
\end{tabular}

Table 7: Number of poly-move complaint realizations in Ukrainian vs. North American verbal repertoires

\section{Conclusions}

The analysis of strategies used by North American vs. Ukrainian respondents has shown that Ukrainian friends apply the whole rank of complaint strategies from the least offensive to the most severe. Native speakers of American English use the most indirect and conventionally indirect strategies. The lexico-syntactic analysis of the complaint strategies found in both repertoires proved that Ukrainians prefer elliptic "to make sure" general questions, elliptic exclamatives and different types of special questions about the particulars of the event, whereas Americans tend to use the full versions of the general "to make sure"-questions, complex clauses with personal/impersonal subjective embedding and what-questions about the event in general. As far as use of internal and external modification markers is concerned, Ukrainians are the ones who tend to aggravate their complaints with different kinds of intensifying particles and slang words, and make their complaints in a single move without any supportive reasons.

The results obtained on the four levels of analysis definitely show that the complaints made by Ukrainians to their friends are more direct and spontaneous, than those performed by North Americans. All this lead us to the main conclusion that the norms of friendship in the two cultures under analysis are different. According to Ukrainian norms friends should be open and sincere with each other, whereas respect for and the right to each other's personal autonomy, which is highly valued in North 
American society, requires greater indirectness on the part of its members. The differences in the friendship norms agree with North American high (91) and Ukrainian low scores (38) along the individualism scale.

\section{Notes}

1. "Face" is the public self-image that every member wants to claim for himself (Brown and Levinson, 1992: 61).

2. Moves are the speaker's behaviours which reflect his/her strategies. These strategies consist of concerted efforts to achieve communication aims. The number and kind of moves within each speech act depends on socio-cultural scripts of communication and is negotiated by interlocutors (Lubecka, 2000: 267).

3. The scores on Hofstede's four dimensions for the countries that Ukraine is compared with can be found at http://www.geert-hofstede.com/hofstede_dimensions.php.

\section{References}

Brown, Penelope and Levinson, Steven (1992): Politeness: Some Universals in Language Usage. Cambridge: Cambridge University Press.

Hall, Edward (1976): Beyond Culture. New York: Doubleday.

Hofstede, Geert and Hofstede, Gert-Jan. (2004 [1991]) Cultures and Organizations: Software of the Mind. New York: McGraw-Hill U.S.A.

Leech, Geoffrey (1983): Principles of Pragmatics. London: Longman.

Lubecka, Anna (2000): Requests, Invitations, Apologies and Compliments in American English and Polish: A Cross-Cultural Communication Perspective. Kraków: Księgarnia Akademicka.

Mikułowski-Pomorski, Jerzy (2006): Jak narody porozumiewaja się ze soba w komunikacji międzykulturowej i komunikowaniu medialnym. Kraków: TAiWPN UNIVERSITAS.

Olshtain, Elite and Liora Weinbach (1993): "Interlanguage features of the speech act of complaining". In G. Kasper and Sh. Blum-Kulka eds., Interlanguage Pragmatics. Oxford: Oxford University Press, 108-122.

Searle, John (1989): Expression and Meaning: Studies in the Theory of Speech Acts. Cambridge: Cambridge University Press.

Shevcehnko, Anna (2005): Ukraine-Culture Smart!: A Quick Guide to Customs and Etiquette. London: Kuperard.

Trosborg, Anna (1995): Interlanguage Pragmatics: Requests, Complaints and Apologies. Berlin-New York: Mouton de Gruyter.

Wierzbicka, Anna (2003): Cross-Cultural Pragmatics: The Semantics of Human Interaction. Berlin-New York: Mouton de Gruyter.

Wolfson, Nessa (1988): "The Bulge: A theory of speech behaviour and social distance". In J. Fine ed., Second Language Discourse: A Textbook of Current Research. Norwood, N.J.: Ablex, 21-38. 